\title{
Can Institutional Investors' Participation Improve Accounting Conservatism in China?
}

\author{
Cheng Min,
} SHU-UTS SILC Business School, Shanghai University, Shanghai, P.R.China

Doi:10.19044/esj.2019.v15n19p149 URL:http://dx.doi.org/10.19044/esj.2019.v15n19p149

\begin{abstract}
Recently many scholars are greatly concerned about the influence of institutional investors on companies' earnings information quality. Institutional investors have strong and professional team. With big fund stake on listed companies, institutional investors are theoretically thought of playing active role in supervising companies to ensure their investment safety and return. Much evidence has showed that institutional investors are becoming active institutional participation from past passive shareholders. The characteristics of institutional show great advantages on exerting their effect on corporate governance. Correspondingly positive behavior of institutional investors will influence the degree of the accounting information quality. Based on this concept, institutional investors can discover in a timely and effective manner problems existing in the accounting information disclosure. As a result, this article examines whether institutional investors as active shareholders can participate in corporate governance in order to improve companies' accounting information quality.
\end{abstract}

Keywords: Institutional investors, accounting conservatism, corporate governance

\section{Introduction}

Institutional investors are important participants in the capital market. After 40 years of development, they have become an important force in the global capital market, especially in mature markets. Whether in developed or developing countries, the proportion of institutions in the structure of investment entities investors has gradually increased, and the tendency of institutionalization in financial markets has become more and more obvious. Especially in the 1980s, with the rise of shareholder activism represented by the California Public Retirement Fund, institutional investors themselves have grown stronger. The growth of capital power has also created conditions for the re-distribution of listed companies' equity in the capital market. The role 
of institutional investors in corporate governance has not been underestimated, and has become important corporate governance mechanism. Global capital markets hope to strengthen their institutional investors and guide them to participate in corporate governance and overcome the original defects in the corporate governance system. Research on investment motives and economic consequences of institutional investors has gradually become a research hotspot of scholars from all over the world. At this stage, whether institutional investors can fully play a positive role in corporate governance is still a topic of widespread controversy in the academic community. Some scholars believe that institutional investors have a large advantage in the amount of funds, professionalism and information acquisition, and the role played in corporate governance is indispensable, which can inhibit the shortsighted selling of major shareholders to certain extent. At the same time, some scholars believe that institutional investors have collusion with major shareholders and infringe on the interests of small and medium investors.

Chinese capital market began to serve Chinese listed companies and investors from the establishment of the Shanghai and Shenzhen A-share market in the 1990s. At the beginning of this century, Chinese Securities Regulatory Commission clearly put forward the slogan of "supernormal development institutional investors", and subsequently issued a series of laws and regulations aimed at promoting capital market reform. It is hoped that institutional investors will play an active role in improving the capital structure of Chinese securities market. With unique governance role to promote the development of listed companies, in the past two decades, institutional investors have become an important participant in the capital market, and have formed a pattern in which securities investment funds are the mainstay and multiple types of investors coexist. The publication of the "Accounting Standards for Business Enterprises" in 1992 marked formal establishment of the position of the conservatism principle in Chinese accounting standards system. In 2013, the General Office of the State Council promulgated the "Opinions on Further Strengthening the Protection of the Legal Rights and Interests of Small and Medium-sized Investors in the Capital Market", which pointed out that safeguarding the legitimate rights and interests of small and medium-sized investors is not only a major purpose of securities supervision, but also the inevitable trend of capital markets development. To protect the right of small and medium-sized investors, one of the important measures is to improve the information disclosure system and fully improve the quality of information disclosure of listed companies. An important goal of China's "13th Five-Year Plan" is to build a multi-level capital market. To promote the development of market participants, regulate the investment behavior of market participants, and gradually improve the external governance mechanism of the market is an important aspect of building a multi-level 
market. In 2016, the " the Governance Guidelines of Listed Companies" issued by the Chinese Securities Regulatory Commission, reaffirming that institutional investors should play a role in many aspects of corporate major issues, director appointments, management incentives and supervision. This predicts that institutional investors as an emerging external and governance mechanism will play an important role in the "13th Five-Year Plan". And correspondingly institutional investors will also play an important role in improving accounting information quality of invested enterprises.

Conservatism is one of the oldest accounting standards in accounting measurement. It has become a recognized accounting practice in the current period. In 2008, scholar Watt elaborated this concept from the perspective of the quality of earnings accounting information. Based on the specific indicators of empirical research, Basu (1997) proposed an inverse regression model and accurate calculation method for measurement of accounting conservatism. He believes that management should promptly record the possible losses, monitor market environment to avoid adverse consequences, and conservatively recognize earnings. Fundamentally, accounting conservatism is one means to ease agency problem. Nowadays, the academic research on accounting conservatism has gradually changed from its origin and development to the direction of corporate governance. As an important criterion for measuring accounting information quality, accounting conservatism helps to reduce agency costs, ease information asymmetry between external investors and corporate management, and improve corporate regulatory efficiency.

The healthy development of institutional investors plays an important role in effective operation of capital market. This paper examines the impact of institutional investors on accounting conservatism based on data from Chinese Shanghai and Shenzhen stock markets.

First, we examine whether shareholdings of institutional investors have influence on accounting conservatism. Compared with individual investors, institutional investors have an advantage in both shareholding and investment strength. Institutional investors have a higher shareholding in listed companies, which makes institutional investors have more voting rights in corporate shareholders' meeting, which is likely to affect management decisions. At the same time, many small and medium-sized shareholders take high cost to collect information, and have weak ability to conduct market analysis independently. With weak information processing capabilities, they tend to show more common "free-riding" behavior and act as followers in the capital market. All these conditions further increase the influence of institutional investors on listed companies.

In addition, with high shareholding scale expected return is also high. When the value of listed companies is increasing, and the possibility of 
institutional investors obtaining higher returns is further increased, which reversely will cause greater losses. In theory, institutional investors have sufficient motivation to participate in corporate governance, but the reality is still open to question. Therefore, this paper takes the data of Chinese listed companies from 2009 to 2015 as a sample to explore the impact of institutional investors' shareholding on the accounting conservatism of listed companies.

Second, we study whether the difference in the stability of institutional investors' shareholdings will have different effects on accounting conservatism. Due to the different sources of funds and their nature, there are usually a variety of institutional investors in capital market. In practice, their operational strategies and management models are also different. For example, for their own interests short-sighted institutional investors often have shortterm operation and investment manipulation, which has also caused great concern from outside world. So, are all types of institutional investors actively involved in corporate governance? Can such supervision be reflected in the robust form of financial reporting? Under the reality of Chinese emerging transition economy, we study whether heterogeneous institutional investors play an active role in stabilizing capital market and improving corporate governance. As expected by the government, institutional investor can reduce principal-agent cost and ease information asymmetry between major shareholders, minority shareholders and management. Thus they play an active role in promoting corporate accounting robustness. However, in terms of all these questions, there are no clear arguments yet. Therefore, this paper will study the influence of institutional investors on accounting conservatism for Chinese domestic Shanghai and Shenzhen A-share listed companies. Starting with the different time and industry dimension from institutional investors to institutional investors, we measure the stability of institutional investors' shareholdings. We further divide institutional investors into stable and transactional types, analyzing their different impact on accounting conservatism.

The development of Chinese capital market has also driven the rapid development of institutional investors. The existing research mainly based on the influence of institutional investors on accounting conservatism has more or less limitations. This paper will define the institutional investors and classify them as stable type and transactional type, combined with China's special national conditions for research. In terms of measuring institutional investors, the shareholding ratio is an indicator widely quoted in many literatures. Based on this, this paper also uses the proportion of institutional investors as the basic indicators of institutional investors' investment behavior. However, different types of institutional investors have different investment motives. In order to analyze the influence of institutional investors on accounting conservatism in a more detailed way, this paper divides 
institutional investors into stable and transactional types from two aspects of time and industry dimension, and further analyzes institutional investors. Both horizontal and vertical aspects were considered. At the same time, the comparison between stable institutional investors and transactional institutional investors shows that transactional institutional investors have a greater impact on accounting conservatism.

\section{Literature review}

In the past three decades, how institutional investors have played a role in corporate governance has always been the focus of academic research. As for how institutional investors influence corporate governance, the three theoretical hypotheses proposed by Pound (1988) fully summarize this: efficient supervision hypothesis, conflict of interest hypothesis and strategic alliance hypothesis. The efficient supervision hypothesis holds that compared with individual investors, institutional investors have sufficient ability and motivation to supervise corporate management, reduce speculative behavior and improve reliability of accounting information quality. Shleifer and Vishny (1997) suggest that institutional investors can play an active role in raising information transparency and reducing agency problems in listed companies. Grier and Zychowicz (1994) found that institutional investors' shareholding ratio and corporate financial leverage are inversely related. The reduction in financial leverage means a decline in corporate financial risk, which fully demonstrates that institutional investors play an effective supervisory role in corporate governance. Chidambaran (2000) research showed that institutional investors play a role in transferring corporate information from management to external investors, effectively reducing information asymmetry between them. Mitra (2005) suggested that a high percentage of institutional investors' shareholding can effectively reduce corporate management's opportunistic behavior. Enriques (2005) also reached the same conclusion in an empirical study based on the Italian market. Xiao Xing (2005) takes the data from Chinese capital market in 2002 as a sample. The study found that institutional investors have already played a role in corporate governance. Zhang Chun (2007) examined the level of governance of institutional investors from the perspective of financing constraints and found that it can alleviate the financing problem of non-state-owned listed companies' over-reliance on internal funds and provide support for the improvement of long-term financing capabilities. In addition, Gao Lei and Zhang Jie (2008) also believe that institutional investors' shareholding levels and corporate governance are on the rise and are negatively correlated with earnings management.

The conflict of interest hypothesis holds that institutional investors

may collude with management to sacrifice the interests of minority shareholders for their own benefit. The strategic alliance hypothesis holds that 
if institutional investors find that the proceeds from collusion with corporate management are higher than the gains from effective supervision; institutional investors may collude with them, thereby damaging the interests of other minority shareholders. Both believe that institutional investors may collude with management. Moreover, institutional investors have obvious shortsightedness, mainly focusing on the arbitrage behavior of short-term stocks, focusing on frequent trading to obtain spreads. This self-interest will be transmitted to the company through price transmission mechanism, which will also cause the company to focus on short-term operation. Bhi (1993) suggested that some institutional investors have behaviors that encourage management to pursue short-term interests. Wahal and Mcfinell (2000) argue that institutional investors have not played their due role in management's shortterm behavior. At the same time, Renneboog (2000) based on the study of the Belgian capital market also proved this point. he pointed out that institutional investors did not really play a role in corporate governance. Grinstein (2005) also pointed out that institutional investors will fully measure the relationship between market returns and governance costs. And only when institutional investors' supervision returns are higher than costs, they will actively take action on possible agency problems. Gao Shenghao and Guan Xinyu (2012) compared the accounting earnings of listed companies with no institutional investors and listed companies with institutional investors. And they found that institutional investors fail to play a role in corporate governance. In addition, some scholars have proposed invalid hypotheses. For example, Admatietall (1994) proposed that in the supervision of corporate management, institutional investors need to pay a certain cost, and each shareholder wants other shareholders to pay the cost to supervise management, which will cause the so-called "free rider" behavior.

Beginning in the 1990s, the fair value under the International Accounting Standards was widely used, and scholars began to conduct systematic research on accounting conservatism. As early as 1924, Bliss (1924) put forward the idea of 'recognizing all losses, but not recognizing all gains', which is also the prototype of the concept of accounting conservatism. Basu (1997) used market price to reflect this trait in preference to accounting information. For accounting earnings, the market response degree of bad news is much higher than those of good news. This result visualized asymmetry and timeliness of accounting conservatism. It is now widely used in the accounting field. In order to study the timeliness of different companies in confirming economic losses, Ball (2005) divided the British companies into two categories, listed and unlisted. It was found that the listed companies recognized the losses faster. He believed that this was mainly due to the different types of companies and their different demand for accounting conservatism. Fangere and Shawky (2003) found that institutional investors 
are more inclined to invest in more stable stocks when the stock market is sluggish.

In China, most scholars believe that institutional investors play a positive role in improving accounting conservatism. Cheng Shuqiang (2006), Wen Zhanglin (2010), and Wang Zhen (2014) have all shown through empirical research that institutional investors can effectively improve the accounting stability of listed companies. However, Chen Aihua (2014) puts forward the opposite view. Based on the perspective of market heterogeneity, he shows that the increase in the shareholding ratio of institutional investors will reduce the accounting conservatism. In addition, Li Kai (2011) found that the different stages of the stock market will lead to differences in accounting conservatism: when the stock market is in the upswing period, institutional investors are easy to collude with management to obtain excess returns. At this time, institutional investors' shareholding is negatively correlated with accounting conservatism, while it is not in a significant relationship during the downturn.

Some scholars also start from the heterogeneity of institutional investors and analyze their relationship with accounting conservatism. The types of institutional investors are found to be different, and their impact on accounting conservatism is also very different. Liu Jingjun and $\mathrm{Xu}$ Haoping (2012) classified them as long-term and short-term institutional investors based on the turnover rate of institutional investors. It is found that short-term institutional investors are more likely to have an impact on accounting conservatism. Zou Xiujing (2014) divided institutional investors into securities investment funds, brokerage firms, insurance companies, social security funds, and QFIIs. It pointed out that securities investment funds and brokerage firms have a significantly lower role in promoting accounting conservatism than social security funds, insurance companies and QFIIs. Wu Lianghai (2017) divided institutional investors into transactional and stable types, and found that stable institutional investors can promote the improvement of corporate accounting conservatism and improve corporate investment efficiency.

As main participators of corporate equity capital, institutional investors play the role of principal in the principal-agent theory, while the management of the invested enterprise is the agent. Therefore information asymmetry and interest conflicts exist between them, which unavoidably results in agency problem. Shleifer (1986) found that compared with the small and medium-sized shareholders in the market, larger institutional investors can effectively supervise corporate management and provide an effective solution to conflict problems of principal-agent relationship between shareholders and management. Therefore, institutional investors, as supplement to external 
governance mechanism, intervene in corporate governance as the principal, which is equivalent to the supervisor in the corporate governance mechanism.

Moreover, institutional investors become corporate shareholders through shareholding, enjoy corporate interests, and strive to seek solutions to information asymmetry in order to protect their own interests. But this approach also needs to consider the issue of excessive supervision costs. Numerous research results show that accounting conservatism can effectively solve information asymmetry problem and keep supervision cost basically unchanged. Watt (2003) proposed that accounting conservatism can effectively reduce moral hazard. Lafond's (2008) study results also shows that because accounting conservatism usually treats profit and loss with required caution, it can effectively reduce information asymmetry between corporate management and external investors. Therefore, institutional investors can reduce information asymmetry without increasing agency costs by means of improving conservatism of accounting information quality. As a result, mature institutional investors have the need and motivation to promote corporate accounting conservatism. Mature institutional investors will supervise and constrain management to ensure that the investment level they choose can maximize corporate long-term value rather than simply meet short-term gain targets, alleviating the principal-agent problems arising from ownership and management rights, and aligning corporate management's Strategic and operational decisions to directly improve corporate performance.

After reviewing research results of domestic and foreign scholars on institutional investors and corporate governance, institutional investors and accounting conservatism, it can be found that internationally, the formulation of accounting conservatism began in the late 20th century, but until the 21th century a few scholars gradually began to get involved in this field. Many research results in this field have proved the importance of accounting conservatism without exception. Early foreign scholars began with the concept of accounting conservatism, refined the classification of various measurement indicators, and completed a series of research process from qualitative to quantitative analyses in this emerging field. With further development of accounting conservatism, research results of domestic scholars are mainly concentrated in two aspects: one is to determine the existence of accounting conservatism in China, and the other is to find some factors that affect accounting conservatism. Chinese capital market has gradually improved after several decades of development, coupled with the strength increase of national supervision and regulation, accounting conservatism has been further enhanced. Scholars who have deeply studied Chinese capital market have also proposed other factors that affect accounting conservatism, such as information disclosure, shareholding structure, accounting system changes since 2007. But with the changing external environment and the annual growth 
of institutional investors, the factors affecting accounting conservatism will also correspondingly change. This paper studies the impact of institutional investor and their heterogeneity on accounting conservatism. Our research results will provide a certain theoretical and practical insight.

At present, the number and types of institutional investors in China continue to increase, and it has become an investment entity that cannot be underestimated in Chinese capital market. With the continuous liberalization of market access restrictions, many types of institutional investors have entered the securities market, and the scale of market entry has been expanding, showing a diversified character. They will inevitably have an impact on the corporate governance of listed companies. The improvement in corporate governance will further improve enterprise business level in an allround way, and the two complement each other. At present, most of the researches take institutional investors as a whole, and take the shareholding ratio as an independent variable to analyze their impact on accounting conservatism from the aspects of information disclosure, financing constraints, and earnings management. Although some researchers also conduct classified studies of institutional investors, their classification is mainly based on the business relationship between institutional investors and listed companies, which is too singular. It should be noted that institutional investors' supervision of listed companies is based on multiple motives, and independence is only one of them. It is inevitable that the institutional investors' shareholding stability differences will be ignored. Therefore, it is necessary to comprehensively consider the impact of different types of institutional investors' shareholding on accounting conservatism. This paper divides institutional investors into stable and transactional types from two aspects of time and industry dimension, and further analyzes institutional investors' impact on accounting conservatives.

\section{Hypothesis development}

Since Basu (1997) used the inverse regression model to quantify accounting conservatism, the influencing factors of accounting conservatism have gradually become the research problems of scholars. The more representative is to use the level of stock returns to measure the level of accounting conservatism. Institutional investors are an important part of corporate governance mechanism. An important assessment of corporate governance participation is to observe the degree of accounting conservatism of the invested company.

In 2000, China Securities Regulatory Commission put forward the slogan of "supernormal development institutional investors", which has played a positive role in promoting the development of institutional investors in China in the past two decades. First of all, institutional investors are a 
professional expert body, which concentrates the funds of most persons and has sufficient strength to become a major shareholder of the company. It has the characteristics of scale effect, portfolio investment and high investment efficiency, and strong capabilities of bearing risk. To ensure the continuity and stability of their return, institutional investors often use their own capital advantages, professional and technological advantages, and information advantages to effectively supervise management in corporate governance and improve accounting conservatism. Secondly, institutional investors are mostly long-term strategic investments. In the past, "voting with the feet" is no longer in line with the law of economic development. When corporate operating conditions are not good, selling stocks may bring shock to the entire stock market. In the long run, institutional investors tend to buy and sell corporate stocks in a more rational way to promote corporate healthy growth in order to obtain long-term regulatory benefits. If institutional investors excessively pursue short-term gains, it will result in a false high accounting earnings and a large amount of expenses and delays in the confirmation of losses. It is difficult to meet the requirements of institutional investors for long-term interests. Therefore, institutional investors have higher requirements to conservatism of accounting information.

At the same time, the role of institutional investors as effective supervisors in corporate governance can also alleviate two types of agency problems: First, institutional investors have a high shareholding ratio and have sufficient incentives to supervise all kinds of self-interested behavior of management. While gaining their interest, it also eases the conflict between shareholders and management. Second, institutional investors, as the thirdparty forces between controlling shareholders and small and medium-sized shareholders, based on their own financial advantages and professional capabilities, have sufficient advantages of alleviating conflicts between controlling shareholders and minority shareholders. When an institutional investor chooses to invest in a listed company, it needs to evaluate the company to prevent and estimate risks. If the company provides conservative financial statements, institutional investors will have a greater chance of choosing the company. Finally, when institutional investors hold corporate shares for a long time, in order to prevent investment risks and protect capital investment at a lower cost, the internal management personnel of the invested enterprise will be supervised, and the motivation to prevent their self-interest will improve accounting conservatism. Furthermore, if conservative financial statements enhance quality of corporate governance, institutional investors can easily obtain value interest from it, which in turn requires management to continue to provide conservative accounting information for each fiscal year. Combining above theoretical analyses, institutional investors have sufficient motivation and demand to supervise the daily operation of the enterprise, 
thereby improving accounting conservatism. Hence, the greater the proportion of institutional shareholding, the higher institutional investors' interest related to corporate performance, they will tend to implement effective supervision and further influence quality of corporate accounting conservatism.

Based on these analyses, we can get hypothesis 1: The total shareholding proportion of institutional investors is positively correlated with accounting conservatism.

In theory, institutional investors have different motives for participating in corporate governance. Some institutional investors have sufficient willingness and sufficient ability to participate in corporate governance, and are not affected by the company's stakeholders. They have a strong motivation to influence the company. On the contrary, some institutional investors lack the strong motivation to participate in corporate governance for a variety of reasons, and are more willing to carry out shortterm investment operations that maximize their own interests. Previous studies have shown that more stable institutional investors can provide long-term incentives for management and focus on improving the company's long-term performance, with less focus on short-term performance and stock price changes.

Institutional investors with short-term view tend to trading and influencing stock prices and managing earnings, forcing companies to pursue short-term interests and weaken corporate core competitiveness. Furthermore, it can be seen that institutional investors with different purposes and stability have different requirements for accounting conservatism.

In the previous discussion, this paper divides institutional investors into stable and transactional types from both the time and industry dimension. Stable institutional investors are institutional investors who hold shares in the listed company for a long time. At present, institutional investors in China are developing rapidly under the policy guidance of vigorously developing institutional investors. In general, various institutional investors have sufficient management experience and investment strategy. But stable institutional investors have a long-term shareholding, pay more attention to improving corporate long-term interests and hope to share corporate future growth interest. So they will actively participate in corporate governance and improve performance stability level. In addition, longer shareholding time and higher shareholding ratio will also increase the weight of institutional investors' participation in management. Long-term investment makes it more influential in the enterprise. For decision-making of corporate long-term orientation, major shareholders and corporate management will consult institutional investors' opinions to a certain extent. The long-term holding time of stable institutional investors also makes them more familiar with the 
internal conditions of enterprises. Hence long-term stable institutional investors will contribute more to improvement of accounting conservatism.

Trading institutional investors mainly use internal information to gain advantages by short-term stock trading. Therefore, improving accounting conservatism has more harm than good for them. At the same time, trading institutional investors usually has weak influence on enterprises, and has a low shareholding ratio, which lacks sufficient influence on management. Shorter holding time also causes trading institutional investors to have less motivation to fully analyze the company's operating conditions. It is more difficult to have a deeper understanding of the company in a shorter period of time. Trading institutional investors have sufficient incentives to conduct short-term transactions under the dual guidance of performance pressure and profitdriven. On the contrary, stable institutional investors tend to use its strong funds, professional investment strategies and internal information advantages to participate in corporate management and governance. Therefore, the influence of transactional institutional investors on accounting conservatism should be lower than that of stable institutional investors. Based on these analyses, combined with hypothesis 1, we can get hypothesis 2: Stable institutional investors have a greater impact on accounting conservatism than trading institutional investors.

\section{Research design}

\subsection{Sample selection and data sources}

This paper takes the A-share listed companies in Shanghai and Shenzhen stock exchanges from 2009 to 2015 as the research object. In order to verify the accuracy and reliability of the research, this paper screens the original data according to the following principles: (1) Excluding the financial and insurance industry companies, because the operation and supervision of this financial industry are different from other companies. (2) Excluding ST, *ST, PT and other companies with special treatment, as there may be problems with financial manipulation. (3) Excluding the IPO companies of the current year because when the listed company first issued shares, its return on equity (ROA) has the possibility of artificially increasing, and the accounting earnings is different from other years with low comparability. (4) Excluding companies without institutional investors' shareholding and with a lack of shareholding ratio for institutional investors in the past three years, as this paper focuses on the impact of institutional investors on accounting conservatism and is measured in terms of time and industry dimensions. The classification of institutional investors requires the use of shareholding ratio data for the past three years. (5) Excluding companies with missing key financial data. After the above screening, the paper finally obtained 11202 observations, including 1065 in 2009, 1202 in 2010, 1534 in 2011, 1686 in 
2012, 1709 in 2013, 1921 in 2014 and 2085 in 2015. In addition, in order to reduce the impact of extreme data on study results, all data were winsorize processed by at the $1 \%$ and $99 \%$ quartiles of the samples.

\subsection{Variables definition}

This paper selects the inverse regression model of BASU:

$$
\mathrm{EPS}_{\mathrm{it}} / \mathrm{P}_{\mathrm{it}-1}=\beta_{0}+\beta_{1} \mathrm{DR}_{\mathrm{it}}+\beta_{2} \operatorname{Ret}_{\mathrm{it}}+\beta_{3} \operatorname{Ret}_{\mathrm{it}} * \mathrm{DR}_{\mathrm{it}}+\mathrm{e}_{\mathrm{it}}
$$

$\mathrm{EPS}_{\text {it }}$ represents the net earnings per share of the company $i$ for the year. $\mathrm{P}_{\mathrm{it}-1}$ is the closing price of the stock at the end of the previous period of company $i$. Ret $t_{i t}$ is the cumulative annual rate of return for company I adjusted by market index. DR is a dummy variable. When Ret $_{i t}<0$, it means bad message, $\mathrm{DR}=1$; otherwise, it takes 0 , which means good news. In the model, $\beta 2$ represents the response degree of accounting earnings to good news, and the sum $(\beta 2+\beta 3)$ represents response degree of accounting earnings to bad news. The difference between the response degree of good news and bad news is the accounting conservatism. Further, when $\beta 3>0$, it indicates that accounting earnings reacts to bad news faster than the good news, that is, the accounting information has the characteristics of conservatism.

This model is a direct reflection of conservatism definition and can be used to measure accounting conservatism more intuitively. The accounting earnings response lags behind the excess return of corporate stock. At the same time, the inverse regression model uses the accounting earnings as the dependent variable and the stock return as the independent variable. At this time, it meets the requirements of the least squares method itself, so this can better set the standard error and variable statistics. In the past research, the model has also been adopted by many scholars, and its effectiveness has been fully verified, so this paper will also use Basu's inverse regression model to measure accounting conservatism.

\subsubsection{Selection of explanatory variables}

(1) Institutional investor shareholding ratio (Ins): In this paper, this indicator is the total number of institutional investors holding shares divided by corporate outstanding common shares.

(2) Proportion of stable institutional investors $\left(\operatorname{Pr}_{\mathrm{i}}\right)$ : When institutional investor sharehoding ratio divided by standard deviation of institutional investor's shareholding in the past three years is greater than or equal to the median of the above ratio in the industry, the company's institutional investors are regarded as stable institutional investors who can actively participate in corporate governance to improve performance.

(3)Trading institutional investor shareholding ratio $\left(\mathrm{Np}_{\mathrm{i}}\right)$ : When institutional investor shareholdings ratio divided by standard deviation of institutional investor's shareholding in the past three years is less than the 
median of the above ratio in the industry, the company's institutional investors are regarded as transactional institutional investors who try to gain excess return through short-term speculation and has a weaker impact on enhancing accounting conservatism.

\subsubsection{Selection of control variables}

In order to better explain the relationship between institutional investors and accounting conservatism, this paper controls the following variables:

(1) Nature of property rights (Soe): The nature of the actual controller of the enterprise. If it is a state-owned enterprise, take 1 and non-state-owned enterprises take 0. Zhu Chafen and Li Zhiwen (2008) show that China's institutional environment is quite special, and because of the existence of "soft budget constraints", equity investors and bond investors focus less on the accounting information of state-owned enterprises, and thus less demand their accounting conservatism. In order to control the difference in accounting conservatism between state-owned enterprises and non-state-owned enterprises, the nature of corporate property rights is regarded as one of the control variables.

(2) Size of the company(Size): It is expressed in terms of the natural logarithm of the total assets at the end of the period. Larger companies have more complex agency relationships, and their information will be concerned by many parties such as tax authorities and securities analysts. The higher the legal cost, the more cautious the disclosure of information, so they are more inclined to disclose conservative financial statements to reduce their legal costs (Khan and Watt, 2009)

(3) Debt ratio (Lev): Total liabilities at the end of the year divided by total assets at the end of the year. The debt ratio is a key indicator of corporate solvency. Companies with higher debt ratios will face greater financial risks, and the pressure on paying principal and interest will be greater, and repayment of liabilities may lead to a decrease in working capital and thus adversely affects company performance. In order to guarantee their own interests, creditors will strengthen their binding role on debt contracts and require more conservative accounting information.

(4) Return on total assets (ROA): The ratio of net profit divided by the average asset balance at the beginning and end of the year. The profitability of a company has a greater impact on the choice of management accounting policies (Xia Donglin and Li Gang, 2008). The stronger the profitability of an enterprise, the more motivated it is to use accounting conservatism. Therefore, ROA needs to be used as a profitability proxy variable to control the impact of profitability on corporate accounting conservatism. 
(5) Ratio of market value of the company to net book value at the end of the year (Mtb): net asset market price/book value. Studies have shown that the degree of uncertainty about earnings and losses (ie, the level of accounting conservatism) is negatively correlated, while Mtb is often used to measure the overall robustness of the overall report. Therefore, it is more reasonable to include the ratio of the year-end market value to the net book value (Mtb) to control their impact on accounting conservatism.

(6) Tobin Q: TobinQ = (end-of-year equity market value + net debt market value) / total assets at the end of the period. For some companies with greater potential for growth, their level of accounting conservatism may be lower due to the motivation of overstating profits. But investors will be more difficult to supervise them, and require them to provide more conservative accounting information. Therefore, TobinQ is regarded as a control variable in this study. The higher the TobinQ value means the higher the return on investment ROI, and institutional investors will have a huge incentive to enter the market.

(7) Industry: excluding the special financial and insurance industry.

Table 1: Variables Definition

\begin{tabular}{|c|c|c|}
\hline \multicolumn{2}{|c|}{ Variable } & Definition and Measurement \\
\hline $\begin{array}{l}\text { Dep } \\
\text { end } \\
\text { ent } \\
\text { vari } \\
\text { able }\end{array}$ & $\mathrm{EPS}_{\mathrm{it}} / \mathrm{P}_{\mathrm{it}-1}$ & $\begin{array}{l}\text { EPS }_{\text {it }} \text { represents the net earnings per share of the company } i \text { for the year. } \\
P_{i t-1} \text { is the closing price of the stock at the end of the previous period of } \\
\text { company i. }\end{array}$ \\
\hline \multirow{5}{*}{$\begin{array}{l}\text { Inde } \\
\text { pen } \\
\text { dent } \\
\text { vari } \\
\text { able }\end{array}$} & $\operatorname{Ret}_{i t}$ & $\begin{array}{l}\text { Ret }_{i t} \text { is the cumulative annual rate of return for company } i \text { adjusted by } \\
\text { market index. }\end{array}$ \\
\hline & Dr & $\begin{array}{l}\text { DR is a dummy variable. When } \text { Ret }_{\text {it }}<0 \text {, it means bad message, } \mathrm{DR}=1 \text {; } \\
\text { otherwise, it takes } 0 \text {, which means good news. }\end{array}$ \\
\hline & Ins & $\begin{array}{l}\text { The total number of institutional investors holding shares divided by } \\
\text { corporate outstanding common shares. }\end{array}$ \\
\hline & $\operatorname{Pr}_{i}$ & $\begin{array}{l}\text { When institutional investor sharehoding ratio divided by standard } \\
\text { deviation of institutional investor's shareholding in the past three years } \\
\text { is greater than or equal to the median of the above ratio in the industry, } \\
\text { the company's institutional investors are regarded as stable institutional } \\
\text { investors. }\end{array}$ \\
\hline & $\mathrm{Np}_{\mathrm{i}}$ & $\begin{array}{l}\text { When institutional investor shareholdings ratio divided by standard } \\
\text { deviation of institutional investor's shareholding in the past three years } \\
\text { is less than the median of the above ratio in the industry, the company's } \\
\text { institutional investors are regarded as transactional institutional } \\
\text { investors }\end{array}$ \\
\hline \multirow{3}{*}{$\begin{array}{l}\text { Con } \\
\text { trol }\end{array}$} & Soe & $\begin{array}{l}\text { The nature of the actual controller of the enterprise. If it is a state- } \\
\text { owned enterprise, take } 1 \text { and non-state-owned enterprises take } 0 \text {. }\end{array}$ \\
\hline & Size & $\begin{array}{l}\text { It is expressed in terms of the natural logarithm of the total assets at the } \\
\text { end of the period. }\end{array}$ \\
\hline & ROA & $\begin{array}{l}\text { The ratio of net profit divided by the average asset balance at the } \\
\text { beginning and end of the year. }\end{array}$ \\
\hline
\end{tabular}




\begin{tabular}{|l|l|l|}
\hline $\begin{array}{l}\text { vari } \\
\text { able }\end{array}$ & Lev & $\begin{array}{l}\text { Total liabilities at the end of the year divided by total assets at the end } \\
\text { of the year. }\end{array}$ \\
\cline { 2 - 3 } & Mtb & $\begin{array}{l}\text { Ratio of market value of the company to net book value at the end of } \\
\text { the year }\end{array}$ \\
\cline { 2 - 3 } & TobinQ & $\begin{array}{l}\text { TobinQ = (end-of-year equity market value + net debt market value) / } \\
\text { total assets at the end of the period. }\end{array}$ \\
\cline { 2 - 3 } & Industry & Excluding the special financial and insurance industry. \\
\hline
\end{tabular}

\subsection{Research model}

In this paper, Basu's inverse regression model is adopted. On the basis of it, the interpret variable and the cross terms of Dr, Ret and Dr*Ret are added. The model is built as follows:

EPSit/Pit-

$1=\beta 0+\beta 1$ Drit $+\beta 2$ Retit $+\beta 3$ Retit $*$ Drit $+\beta 4 *$ Insit $+\beta 5 *$ Drit $*$ Insit $+\beta 6 *$ Retit $*$ Insit $+\beta 7 *$ Drit*Insit*Retit+controlit+eit

Init indicates that institutional investors' shareholding proportion at the end of year $t$, and join the control variable Soe, which represents enterprise nature, company size Size, Debt ratio Lev, total return on assets Roa, company's year-end market value to net book value Mtb Tobin Q, industry control variable, mainly to investigate the impact of the coefficient $\beta 7$ of the interactive term DRit*Insit*Retit on accounting conservatism. According to the hypothesis 1 of this paper, $\beta 7$ should be greater than 0 . In the test of Hypothesis 2, the institutional investors are classified into stable and trading types according to the previous analysis, and are substituted into the model for testing, namely:

EPSit/Pit-

$1=\beta 0+\beta 1$ Drit $+\beta 2$ Retit $+\beta 3$ Retit $*$ Drit $+\beta 4 *$ Priit $+\beta 5 *$ Drit $*$ Priit $+\beta 6 *$ Retit $*$ Priit $+\beta 7 *$ Drit*Priit*Retit+controlit+eit

EPSit/Pit-

$1=\beta 0+\beta 1$ Drit $+\beta 2$ Retit $+\beta 3$ Retit $*$ Drit $+\beta 4 * N p i i t+\beta 5^{*}$ Drit $*$ Npiit $+\beta 6 *$ Retit*Np

iit $+\beta 7 *$ Drit $*$ Npiit $*$ Retit+controlit+eit

\section{Empirical results}

5.1 Descriptive analyses

\begin{tabular}{|l|l|l|l|l|}
\hline Mean & St.Dev & Median & Max & Min \\
\hline
\end{tabular}

Table 2: Descriptive Statistics

\begin{tabular}{lccccccc}
\hline & Variable & $N$ & Mean & \multicolumn{1}{c}{ Median } & St.Dev & Max & Min \\
\hline EPS/Pit-1 11202 & 0.029 & 0.024 & 0.040 & 0.168 & -0.154 \\
Ret & 11202 & 0.267 & 0.039 & 0.683 & 3.038 & -0.527 \\
Dr & 11202 & 0.466 & 0.000 & 0.499 & 1.000 & 0.000 \\
Ins & 11202 & 0.410 & 0.414 & 0.229 & 0.985 & 0.000 \\
Pri & 5658 & 0.485 & 0.493 & 0.200 & 0.985 & 0.028
\end{tabular}




\begin{tabular}{lllllll} 
Npi & 5544 & 0.333 & 0.305 & 0.230 & 0.982 & 0.000 \\
Soe & 11202 & 0.457 & 0.000 & 0.498 & 1.000 & 0.000 \\
Size & 11202 & 22.129 & 21.947 & 1.247 & 25.912 & 19.742 \\
Roa & 11202 & 0.042 & 0.037 & 0.051 & 0.203 & -0.156 \\
Lev & 11202 & 0.453 & 0.456 & 0.211 & 0.896 & 0.050 \\
Mtb & 11202 & 1.618 & 1.214 & 1.024 & 5.128 & 0.086 \\
TobinQ & 11202 & 2.219 & 1.628 & 2.021 & 11.681 & 0.195 \\
\hline
\end{tabular}

In this sample, the average earnings per share of Eps/Pit-1 is 0.029, the median value is 0.024 , slightly right-biased, and the average value of the total sample middle-year stock return rate Ret of 0.267 is significantly greater than the Ret median of 0.039 , indicating the annual stock return rate is unevenly distributed with a significant right deviation. From the distribution characteristics of accounting earnings Eps/Pit-1 and annual stock return rate Ret, the accounting earnings' market responses are asymmetrical to the good news and bad news, that is, the losses are confirmed more timely than the gains.

The median and average value of accounting earnings per share Eps/Pit-1 are greater than 0, indicating that the listed company selected in this study is profitable overall, the overall economic environment is better, and the maximum value is 0.168 , the minimum value is -0.154 , each group of data is guaranteed to have appropriate differences. From the volatility of the two, Ret's standard deviation is 0.6846 , which is much larger than the standard deviation of per share accounting earnings Eps/Pit-1 of 0.040, indicating that the volatility of stock returns is higher than the accounting earnings per share, which is in line with the emerging country capital market. The characteristics indicate that accounting conservatism exists within the sample interval.The average market value to book value is 1.618 , and the median is 1.214 , both of which are greater than 1 . This indicates that the market value of listed companies in China is greater than the book value, and its financial statements can reflect the accounting conservatism.

The average return on assets Roa is 0.042 , and the median value is 0.037, which indicates that the overall profit level of the sample companies selected is slightly lower. This is mainly because the sample of this study is selected from listed companies in Shanghai and Shenzhen A-shares, and most of them have grown and matured. During the period, profitability has gradually stabilized. The overall shareholding ratio of institutional investors is 0.410 , the maximum value is 0.985 , and the minimum value is 0.000 , indicating that the institutional investors in China are generally unevenly distributed, and the polarization between the two poles is more serious, which may be related to the status of individual stocks. In terms of enterprise nature Soe, its average value is 0.457 , which indicates that the number of state-owned enterprises and non-state-owned enterprises in China's capital market is 
basically balanced. The number of non-state-owned enterprises is slightly more, which is consistent with the basic situation of China's capital market and is representative. The median and mean values of TobinQ in the sample are all greater than 1, indicating that the market value of listed companies in China is higher than the replacement cost. Enterprises will continue to increase investment expenditures in pursuit of maximizing value.

\subsection{Regression results}

Table 3 show regression results of the four models as follows: (1) the basic Basu model, that is, the accounting robustness is tested; (2) the influence of the institutional investor's total shareholding ratio Ins on accounting conservatism; 3) The impact of stable institutional investors Pri on accounting conservatism; (4) The impact of trading-type institutional investors Npi on accounting conservatism. Model 1 is the Basu inverse regression model. Substituting the sample data of this paper gives the regression results of (1) in Table 3. The coefficient $\beta 3$ of Ret*Dr is 0.117 ( $\mathrm{T}$ value is 10.544 ), which is significantly positive at the level of $1 \%$, indicating that the bad news reacts faster in the accounting earnings than the good news. The sum of the coefficient $\beta_{2}$ and $\beta_{3}$ is 0.175 , which is greater than the reaction degree of accounting earnings on good news $\beta 2$, which proves that the accounting conservatism is widely present in the listed enterprises in China.

Model 2 adds explanatory variables and control variables to model 1. The regression results in (2) of table 3 are tests for hypothesis 1 . The results show that the coefficient of Ins* Dr*Ret is 0.084 (Tvalue is 5.549), which is significantly positive at the $1 \%$ level, indicating that institutional investors can effectively improve accounting conservatism, thus proving that hypothesis 1 indicates that the higher the proportion of institutional investors in China, the better the accounting conservatism. That is, the proportion of institutional investors' shares is positively related to accounting conservatism. This positive impact stems from the natural characteristics of institutional investors who seek to maximize their benefits by forming a contractual relationship with small and medium investors to obtain their funds and investment. On the one hand, compared with small and medium-sized individual investors, institutional investors have the characteristics of low information cost, reasonable risk diversification, high-scale benefits and strong supervision. Therefore, as an important external shareholder of the company, they are more willing to pay attention to the development of listed companies. With larger amount of investment funds and professional team, institutional investors are more motivated to supervise corporate operating and financial level to gain long-term return. Conservative accounting information provides a low-cost and effective indirect mean for obtaining this supervision information. On the other hand, due to the consideration of principal-agent relationship and subject 
to the constraints of the regulatory authorities, behavioral interventions of institutional investors participating corporate governance have been strongly limited. In the long run, after trading off between investment return and monitoring costs, institutional investors will choose to supervise the management of the invested entity through accounting conservatism rather than direct intervention.

On the basis of Hypothesis 1, this paper divides institutional investors into two types: stable and transactional, according to the two dimensions of investment time and industry. Models 3 and 4 are respectively constructed to verify hypothesis 2 . In Table 3, (3) is the regression result of stable institutional investors on accounting conservatism, and (4) is the regression result of transactional institutional investors on accounting conservatism. In (3), the coefficient of Pri* Dr*Ret is 0.069 ( $\mathrm{T}$ value is 2.584), and the coefficient of Npi* Dr*Ret in (4) is 0.055 (T value is 3.010), at a significance level of $1 \%$. The coefficient is significantly positive, indicating that stable institutional investors and transactional institutional investors are positively correlated with accounting conservatism. By comparing the coefficient value, the impact of stable institutional investors on accounting conservatism is significantly higher than that of transactional institutional investors, thus proving hypothesis 2 . This shows that in Chinese capital market, the positive impact of listed companies on accounting conservatism is mainly due to stable institutional investors, while the trading institutional investors have a slightly weaker impact on the accounting conservatism of the invested companies. This may be due to the fact that stable institutional investors tend to prefer long-term investing shareholdings. The amount of investment and the scale is relatively large. The leverage effect of gains and losses from the investment is more obvious, so they have stronger motivation to monitor management. A simple and effective way to supervise is to require management to provide more conservative financial reporting, so they will require higher accounting conservatism for listed companies. However stability indicators of transactional institutional investor are lower than the median of the industry in that year. Their lower shareholding stability makes it less demanding on the quality of accounting information of listed companies. Therefore stable institutional investors have a higher impact on accounting conservatism than transactional institutional investors. 
Table 3: Regression Results of Institutions 'shareholdings on Accounting Conservatism

\begin{tabular}{|c|c|c|c|c|}
\hline & Variable & (1) & (3) & (4) \\
\hline \multirow[t]{2}{*}{ Intercept } & $-0.103^{* * * *}$ & $-0.107^{* * *}$ & $-0.105^{* * *}$ & $-0.110^{* * * *}$ \\
\hline & $(-15.501)$ & $(-15.646)$ & $(-10.357)$ & $(-11.958)$ \\
\hline Dr & $\begin{array}{r}-0.038^{* * * *} \\
(-3.197)\end{array}$ & $\begin{array}{c}-0.039^{* * *} \\
(-3.328)\end{array}$ & $\begin{array}{c}-0.066^{* * * *} \\
(-3.962)\end{array}$ & $\begin{array}{l}-0.010 \\
(-0.593)\end{array}$ \\
\hline Ret & $\begin{array}{r}0.058^{* * *} \\
(6.209)\end{array}$ & $\begin{array}{r}0.058^{* * *} \\
(6.202)\end{array}$ & $\begin{array}{r}0.050^{* * *} \\
(3.802)\end{array}$ & $\begin{array}{l}0.069^{* * *} \\
(5.199)\end{array}$ \\
\hline Dr*Ret & $\begin{array}{c}0.117^{* * * *} \\
(10.544)\end{array}$ & $\begin{array}{l}0.047^{* * * *} \\
(2.851)\end{array}$ & $\begin{array}{l}0.061^{* * *} \\
(2.122)\end{array}$ & $\begin{array}{c}0.065^{* * *} \\
(3.146)\end{array}$ \\
\hline Ins & & $0.020^{* * * *}$ & $(2.242)$ & \\
\hline \multicolumn{2}{|c|}{ Ins* Dr*Ret } & $0.084^{* * *}$ & (5.649) & \\
\hline Pri & \multicolumn{4}{|c|}{$-0.021^{* * *}$} \\
\hline \multicolumn{2}{|c|}{ Pri* Dr*Ret } & \multicolumn{3}{|c|}{$\begin{array}{r}0.069^{* * * *}(-1.639) \\
(2.584)\end{array}$} \\
\hline \multicolumn{2}{|l|}{ Npi } & \multicolumn{3}{|c|}{$0.033^{* * *}$} \\
\hline \multicolumn{2}{|c|}{ Npi* Dr*Ret } & & \multicolumn{2}{|c|}{$\begin{array}{l}0.055^{* * *} \\
(3.010)\end{array}$} \\
\hline AdjustR $^{2}$ & 0.494 & 0.496 & 0.494 & 0.502 \\
\hline F-statistic & 257.015 & 161.176 & 100.441 & 62.419 \\
\hline $\mathrm{N}$ & 11202 & 11202 & 5658 & 44 \\
\hline
\end{tabular}

\subsection{Robustness test}

Regression results of the model selected in this paper respectively prove the hypothesis 1 and 2, which support the inspection role of institutional investors by examining their impact on accounting conservatism. In order to prove that the above results are not accidental and avoid endogeneity, this paper also uses institutional data with one year lagged to build model 3:

$\mathrm{EPS}_{\mathrm{it}} / \mathrm{P}_{\mathrm{it}}$

${ }_{1}=\beta_{0}+\beta_{1} \mathrm{DR}_{\mathrm{it}}+\beta_{2} \operatorname{Ret}_{\mathrm{it}}+\beta_{3} \operatorname{Ret}_{\mathrm{it}} * \mathrm{DR}_{\mathrm{it}}+\beta_{4} * \operatorname{Ins}_{\mathrm{it}+1}+\beta_{5} * \mathrm{DR}_{\mathrm{it}} * \operatorname{Ins}_{\mathrm{it}+1}+\beta_{6} * \operatorname{Ret}_{\mathrm{it}} *$ Ins $_{\mathrm{it}+1}$ $+\beta_{7} * \mathrm{DR}_{\mathrm{it}} * \operatorname{Ins}_{\mathrm{it}+1} * \operatorname{Ret}_{\mathrm{it}}+$ control $_{\mathrm{it}}+\mathrm{e}_{\mathrm{it}}$

Table 4 below is the regression result of one-year lagged institutional investors' shareholding on accounting conservatism. It can be found that the coefficient of Dr*Ret in (1) is 0.117 , which is positive at the significant level of $1 \%$; (2) The coefficient of Ins* Dr*Ret is 0.084 , which is also positive at the $1 \%$ significance level. The regression results of both indicate that the empirical data is robust. Total institutional shareholding ratio and accounting conservatism are still positive. In addition, in (3) and (4), both the stable and 
trading institutional investors have passed the significant test at the $1 \%$ level. By comparing the correlation coefficient between the stable and trading institutional investors, we found that the accounting conservatism level of stable institutional investors was higher than that of passive institutional investors, and both hypotheses 1 and 2 were verified.

Table 4: Robustness test results

\begin{tabular}{|c|c|c|c|c|}
\hline \multirow{2}{*}{$\begin{array}{l}\text { Variable } \\
\text { Intercept }\end{array}$} & (1) & (2) & \multicolumn{2}{|l|}{ (3) } \\
\hline & $-0.103 * *$ & $-0.107 * *$ & $-0.105 * *$ & $-0.110 * * *$ \\
\hline & $(-15.501)$ & $(-15.646)$ & $(-10.357)$ & $(-11.958)$ \\
\hline \multirow{2}{*}{ Dr } & $-0.038 * * *$ & $-0.039 * * *$ & $-0.066^{* * * *}$ & -0.010 \\
\hline & $(-3.197)$ & $(-3.328)$ & $(-3.962)$ & $(-0.593)$ \\
\hline \multirow[t]{2}{*}{ Ret } & $0.058 * * *$ & $0.058 * * *$ & $0.050 * * *$ & $0.069 * * *$ \\
\hline & $(6.209)$ & $(6.202)$ & (3.802) & (5.199) \\
\hline \multirow[t]{2}{*}{ Dr*Ret } & $0.117 * * *$ & $0.047 * * *$ & $0.061 * * *$ & $0.065^{* * *}$ \\
\hline & (10.544) & $(2.851)$ & $(2.122)$ & (3.146) \\
\hline Ins & $\begin{array}{r}0 \\
(2 .\end{array}$ & $\begin{array}{l}20 * * * \\
42)\end{array}$ & & \\
\hline Ins* Dr*Re & Ret & $\begin{array}{l}0.084 * * * \\
49)\end{array}$ & & \\
\hline Pri & & $\begin{array}{l}-0.021 \\
(-1.639)\end{array}$ & **** & \\
\hline Pri* Dr*Re & & $\begin{array}{r}0 \\
(2.584)\end{array}$ & $.069 * * *$ & \\
\hline Npi & \multicolumn{4}{|c|}{$\begin{array}{l}0.033 * * * \\
(2.716)\end{array}$} \\
\hline \multicolumn{2}{|c|}{ Npi* Dr*Ret } & \multicolumn{3}{|c|}{$(3.010)^{0.055^{* * *}}$} \\
\hline AdjustR2 & 0.494 & 0.496 & 0.494 & 0.502 \\
\hline F-statistic & 257.015 & 161.176 & 100.441 & 62.419 \\
\hline $\mathrm{N}$ & 11202 & 11202 & 5658 & 544 \\
\hline
\end{tabular}

\section{Conclusions}

This paper takes the China-Shenzhen A-share market in 2009-2015 as the research object, and combines principal-agent theory, information asymmetry theory and cost-benefit theory to analyze the influence of institutional investors' shareholding on accounting conservatism and further study the heterogeneity of institutional shareholding. Firstly, we examine the overall impact of institutional investors on accounting conservatism. Then according to industry and shareholding period, we divide institutional investors into stable and transactional type. The impact of stable and transactional institutional investors on accounting conservatism is further verified. The conclusions of the study are as follows: 
(1) The proportion of total shareholding of institutional investors is positively related to accounting conservatism. The main reason is that institutional investors have higher demand for conservative accounting information. Institutional investors themselves have a higher shareholding ratio in listed companies, so they have strong incentives and sufficient possibilities to interfere with relevant decisions of controlling shareholders and management. Their supervision reduces damage to accounting conservatism caused by inappropriate decisions, promoting the improvement of accounting information quality.

(2) Stable institutional investors have a greater impact on accounting conservatism than transactional investors. Both stable and trading institutional investors can promote the improvement of accounting conservatism, but the former has a greater impact. This is mainly due to the fact that stable institutional investors have a high proportion of shares and long-term shareholding period. They have preferences to long-term stable investments and tend to obtain long-term stable returns through the increase in the market value of the invested companies. Transactional institutional investors pay more attention to the market performance of short-term stocks, and generally have more commercial links with the invested companies. To some extent this avoids the investment loss caused by information asymmetry. Therefore, compared with stable institutional investors, Transactional institutional investors' requirements for accounting conservatism are relatively low.

The research in this paper provides direct evidence for the positive role played by institutional investors in corporate governance. It not only helps to understand the economic characteristics of accounting conservatism, but also integrates the achievements of predecessors and provides empirical evidence about the significant positive relationship between stable institutional investors and accounting conservatism. The research conclusions show that actively promoting the development of institutional investors, especially stable institutional investors, is an important means to improve the accounting conservatism of listed companies in China.

\section{References:}

1. Ahmed, B. Billings, M.S. Harris and R.M. Morton. 2002. Accouting conservatism and cost of debt: An empirical test of efficient contracting. The Accounting Review,4:867-890

2. Agrawal A,Knoeber C R. 1996. Firm Performance and mechanisms to control agency Problems between managers and shareholders[J].Journal of Financial and Quantitative Analysis, 31: 77397. 
3. Ball, R. , S.P.Kothari, A. Robin.2000. The effect of international institutional factors on properties of accounting earnings[J]. Journal of Accounting and Economics, 2000,29(1):1-51.

4. Ball R, L. Shivakumar. 2005. Earnings quality in UK Private firms: Comparative loss recognition timeliness[J]. Journal of Accounting and Economics, 39:83-128

5. Basu. S. 1997.The Conservatism Principle and the Asymmetric Timeliness of Earnings[J]. Journal of Accounting and Economics, 1:3-37

6. Ding, Y. , H. 2006. Stolowy. Timeliness and consevatism: Changes over time in the properties of accounting income in France[J]. Review of Accounting and Finance,5(2):92-107.

7. Huijgen, C, Lubberink, M. 2005. Earnings conservatism, litigation, and contracting: the case of cross-listed firms[J]. Journal of Business Finance and Accounting, 32:1275-1310

8. Lara J. M.G, A. Mora. 2004. Balance sheet versus earnings conservatism in Europe[J]. Europe Accuouting Review, 2004, 13(2):261-292.

9. Lipton. M, S.A., 1991, Rosenblum. A New System of Corporate Governance: The Quinquennial Election of Directors[J]. The University of Chicago Law Review,58(1):187-253.

10. Webb, R, M. Beck, R. McKimon. 2003.Problems and Limitations of Institutional Investor Participation in Corporate Govemance [J] .Institutional Investor Paticipation, 11:65-73. 